\title{
Characterization of differential expression and leader intron function of Arabidopsis atTOC159 homologous genes by transgenic plants
}

\author{
Yu-Shan Liu and Chih-Wen Sun
}

\begin{abstract}
Background: Accurate import of thousands of nuclear-encoded proteins is an important step in plastid biogenesis. However, the import machinery of cytosolic precursor proteins to plastids relies on the Toc and Tic (translocons on the outer envelope and inner envelope membrane of chloroplasts) complexes. Toc159 protein was identified in pea (Pisum sativum) as a major receptor for the precursor proteins. In Arabidopsis thaliana, four psToc159 homologs are identified, termed atToc159, atToc132, atToc120 and atToc90. The expression of these protein-encoding genes has to be properly regulated, because their gene products must be correctly integrated to appropriate apparatus to perform their functions.

Results: In order to elucidate the regulatory mechanisms of atTOC159 homologous gene expression, transgenes containing various lengths of the upstream regulatory sequences of atTOC159/atTOC132/atTOC120/atTOC90 and GUS coding sequence were transferred to wild type Arabidopsis. In accordance with the analysis of GUS activity in these transgenic plants at various developmental stages, these homologous genes had distinct expression patterns. AtTOC159 and atTOC90 are preferentially expressed in above-ground tissues, such as cotyledons and leaves. In mature roots, atTOC159 and atTOC132 are expressed at higher levels, while atTOC120 and atTOC90 are expressed at the basal level. All four genes have increased expression level during flower and fruit development, particularly a remarkably high expression level of atTOC159 in later stage of fruit development. Furthermore, leader intron in the 5' UTR induces the expression level of atTOC159 members in a tissue-specific manner. This is able to up-regulate the atTOC120 expression in roots/leaves/flowers, and the atTOC90 expression in cotyledons/leaves/anthers.
\end{abstract}

Conclusions: The differential expression of atTOC159 gene members is essential during plastid development, because proper atToc159 isoforms are required to import distinct proteins to the plastids of different tissues.

Keywords: Arabidopsis thaliana; atTOC159 homologous genes; Transgenic plant; Promoter activity; Reporter gene; Leader intron

\section{Background}

From an engulfed cyanobacterial ancestor, plastid is nowadays converted into three major groups in the plant cell, according to its function and location. Chloroplasts ubiquitously exist in the cells of green tissues, and are responsible for photosynthesis, the synthesis of amino acids and lipids, the synthesis of phytohormones, and the storage of starch and oil compounds. Chromoplasts appear in the cells of leaves, flowers and fruits, and are

\footnotetext{
* Correspondence: cwsun@ntnu.edu.tw

Department of Life Science, National Taiwan Normal University, Taipei 116, Taiwan
}

predominantly responsible for the synthesis of pigments. Amyloplasts majorly exist in the root cells and minor in the stem cells, functioning as the storage of starch and the gravity sensor. However, more than $90 \%$ of the plastid genes have since been transferred to the host nucleus during evolution (Martin et al., 2002). In consequence, these nuclear-encoded plastid-localized proteins must be correctly imported to the plastids during the processes of plastid biogenesis to guarantee proper plastid functions.

Except for a few outer membrane proteins, most of the nuclear-encoded plastid proteins are imported into plastids via a set of translocon components located at the outer/inner envelope membrane of chloroplasts (Toc 
and Tic; Inaba and Schnell, 2008). Toc34 and Toc159 are Toc core-complex components, and also identified as GTPases. They are in charge of recognizing preprotein, and thus are regarded as receptors for the preprotein (Jarvis, 2008). In Arabidopsis, Toc34 and Toc159 are encoded by multiple genes. AtTOC33 (At1g02880) and atTOC34 (At5g05000) are homologous to pea psTOC34 (Jarvis et al., 1998), whereas atTOC159 (At4g02510), atTOC132 (At2g16640), atTOC120 (At3g16620) and atTOC90 (At5g20300) are homologous to psTOC159 (Bauer et al., 2000). Genetic and biochemical analyses revealed that different receptor isoforms encoded by these gene families had distinct functions. AtToc33 and atToc159/atToc90 are probably the receptors specific for photosynthesis-related proteins (Jarvis et al., 1998; Bauer et al., 2000; Kubis et al., 2003; Hiltbrunner et al., 2004). However, atToc 34 and atToc132/atToc120 are prone to recognize non-photosynthetic proteins and import them into plastids (Ivanova et al., 2004; Kubis et al., 2004).

Since atToc159 protein isoforms might recognize and allow to import diverse plastid proteins, atTOC159 homologous genes should be independently regulated during the process of vegetative and reproductive development. In fact, the regulation of atTOC159 gene members in several organs had been reported. Bauer et al. (2000) showed that the expression of the mRNA level of atTOC159 was five to ten times more than that of atTOC132 and atTOC120 in both 6-day-old etiolated and green seedling, indicating that atTOC159 is predominantly expressed in young seedling. Furthermore, Kubis et al. (2004) showed that atTOC159 was strongly expressed in 10-day-old leaves, atTOC90 was expressed at a uniformly moderate level in leaves/inflorescence/ roots, whereas atTOC132 and atTOC120 were expressed at a uniformly low level but relatively prominent in inflorescence and roots. The expression level of atTOC90 in 28-day-old leaves, inflorescence and roots were approximately 3 times, 1.3 times and 5 times, respectively, higher than that of atTOC159. By contrast, the Gene Chronologer tool in Genevestigator revealed that atTOC159 had 4 to 5 times higher expression than atTOC90 in mature leaves and inflorescence (Zimmermann et al., 2004). Additional analyses are clearly needed to elucidate these conflicting results.

In this study, the differential expression of atTOC159 homologous genes regulated by their upstream sequence in the vegetative and reproductive tissues was analyzed. We first created stable transgenic plants expressing the GUS reporter gene driven by the upstream sequences of atTOC159 family members and determined the GUS activity of these transgenic plants. Our results suggest that atTOC159 and atTOC 90 are preferentially expressed in 1-and 2-week-old leaves, whereas
atTOC159 and atTOC132 have relative higher expression levels in 21-day-old roots. All atTOC159 homologous genes have increased expression level in flowers and siliques, especially a remarkably higher expression level of atTOC159 in later stage of fruit development. The intron effect on the transcription activity was also examined by analyzing GUS activity in the stable transgenic plants. Our results show that the expression yield of atTOC120 is dramatically up-regulated in root tip and flowers by its leader intron sequence (the intron nearest to the transcription start site), while that of atTOC 90 is significantly up-regulated in cotyledons and anthers.

\section{Methods}

\section{Plant material and growth conditions}

Arabidopsis seeds from wild type (ecotype Columbia) and transgenic plants were surface sterilized with $25 \%$ $(\mathrm{v} / \mathrm{v})$ commercial bleach. For preparation of rosette leaves, seeds were germinated on $1 \times$ MS (Murashige and Skoog 1962) agar medium with Gamborg's vitamins and $2 \%(\mathrm{w} / \mathrm{v})$ sucrose. For preparation of flowers and siliques, seeds were directly sowed on soil. For preparation of roots, seeds were germinated and grown in distilled water for 5 days and then transferred to nutrient solution for 16 days by means of a hydroponic system (Araponics). The nutrient solution was renewed every three day and the recipe was based on Fan et al. (2009). Plants were grown at $22^{\circ} \mathrm{C}$ under a 16-h light/8-h dark cycle in white light $\left(85 \mu \mathrm{mol} \mathrm{m}{ }^{-2} \mathrm{sec}^{-1}\right)$ for various numbers of days.

\section{Plasmid construction and plant transformation}

The upstream sequences of atTOC159, atTOC132, atTOC120 and atTOC90 genes were amplified by PCR and ligated into $\beta$-glucuronidase (GUS)-containing binary vector pCAMBIA1391Z (GenBank accession number AF234312). The resulting plasmids were transformed into wild type plants using the floral dipping method (Clough and Bent, 1998), mediated by Agrobacterium strain GV3101. The transformants were selected on agar plates containing $30 \mu \mathrm{g} / \mathrm{mL}$ hygromycin, and verified by PCR using construct-specific primers. These transformants were named 159PUI, 132PUI/132P, 120PUI/120P and 90PUI/90P, representing different lengths of upstream sequences, respectively (Figure 1). The $1391 \mathrm{Z}$ plant was transgenic plant containing pCAMBIA1391Z plasmid, and therefore served as negative control. The transgenic plants were selected for more than two generations and $\mathrm{T}_{3}$ homozygous transgenic plants were used for this study. The primer sequences specific for atTOC159, atTOC132, atTOC120 and atTOC90 upstream sequences are summarized in Table 1. 


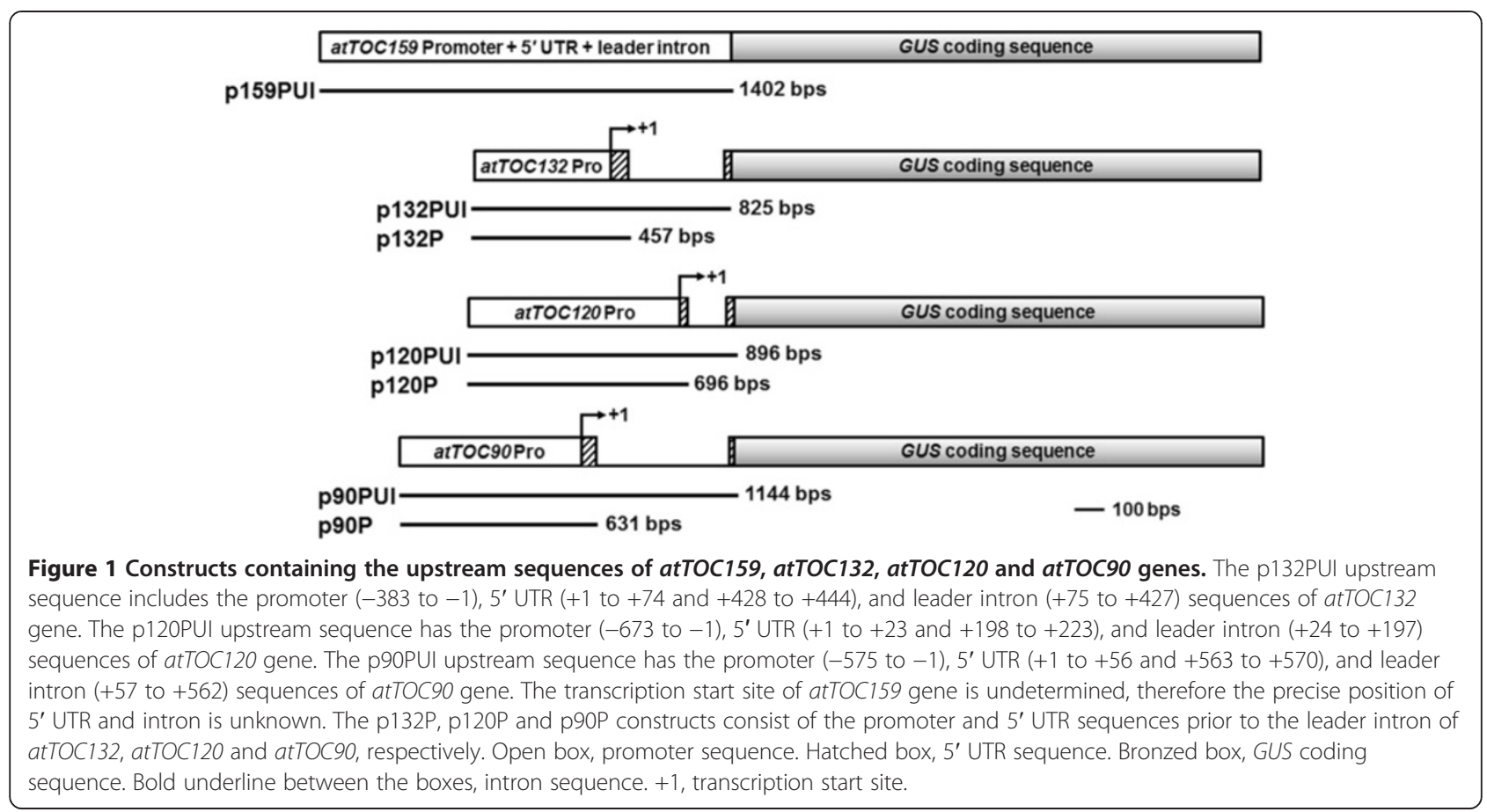

\section{GUS activity assays}

The fluorometric quantification and histochemical localization of GUS enzyme activity were performed as described by Jefferson (1987). For fluorometric quantification, cell lysate was assayed for GUS activity with fluorometer (SpectraMax Gemini XPS, Molecular Devices). For histochemical staining, the plant tissues were incubated in GUS buffer for 1.5 to 24 hours at $37^{\circ} \mathrm{C}$, and stored in fix solution $(0.1 \mathrm{M}$ sodium phosphate, $\mathrm{pH} 7.2,0.1 \%$ formaldehyde, $0.1 \%$ triton $\mathrm{X}-100$, $0.1 \% \beta$-mercaptoethanol).

\section{Results}

\section{Preferential expression of atTOC159 and atTOC90 in leaves}

To determine whether the expression of atTOC159 homologous genes was influenced by tissue-specific signals, promoter-GUS fusions were constructed for atToc159 family members and analyzed in transgenic Arabidopsis plants. Approximately 1-kb upstream sequences of atTOC159 homologs were individually placed into a binary vector pCAMBIA1391Z containing a GUS coding sequence as a reporter. The resulting constructs p159PUI, p132PUI, p120PUI and p90PUI contained a 1.4-kb, $0.82-\mathrm{kb}, 0.89-\mathrm{kb}$ and $1.14-\mathrm{kb}$ upstream sequences of atTOC159, atTOC132, atTOC120 and atTOC90 genes, respectively (Figure 1). These plasmids were further transformed into wild type Arabidopsis by the floral dipping method. Twenty one, nine, nine and fourteen independent transgenic lines containing p159PUI, p132PUI, p120PUI and p90PUI, respectively, were obtained. These transgenic plants were named 159PUI-1 21, 132PUI-1 9, 120PUI-1 $\sim 9$, and 90PUI-1 $\sim 14$. Three homozygous $\mathrm{T}_{3}$ transformants representing each construct were used for further GUS analyses.

The GUS activity in 1-to 2-week-old leaves of various transgenic plants was compared first. Among these transgenic plants, the GUS activity of 159PUI and 120

Table 1 Sequences of gene-specific primers used in this study

\begin{tabular}{|c|c|c|}
\hline Gene & Forward primers $\left(5^{\prime} \text { to } 3^{\prime}\right)^{a}$ & Reverse primers $\left(5^{\prime} \text { to } 3^{\prime}\right)^{a}$ \\
\hline 159PUI & GCCAAGCTTGGATTTGTGTTATGTTTCTCGC & CGGGGATCCCCGCTITGCTACTGAGACTC \\
\hline $132 \mathrm{PUI}$ & GCCAAGCTTTAGCTGCACCAGCTTATTGAG & CGGGGATCCTCTAGATCACCACCGCTACG \\
\hline $132 P$ & GCCAAGCTTTAGCTGCACCAGCTTATTGAG & CGGGGATCCCAGAAGTTAGAGATAGAGAGAG \\
\hline $120 \mathrm{PUI}$ & GCCAAGCTTAGTGTGGTGTTGTTTAAGTGTG & CGGGGATCCCTAGGATCACCCAAAATCACG \\
\hline $120 P$ & GCCAAGCTTAGTGTGGTGTTGTTTAAGTGTG & CGGGGATCCCTGGTTAGAGAAGGCAAAAGTC \\
\hline 90PUI & GCCAAGCTTAGACGAAGATGTCGTCATTGG & CGGGGATCCAACTATCTGCCCAACAGCAAG \\
\hline $90 P$ & GCCAAGCTTAGACGAAGATGTCGTCATTGG & CGGGGATCCTTGTGTTGGCGAGAGAAAGAG \\
\hline
\end{tabular}

The underlined sequences are additional restriction sites. BamHI, GGATCC; HindllI, AAGCTT. 
PUI transformants had the highest and lowest expression levels in 1-week-old leaves, respectively (Figure 2). Their GUS expression levels in 2-week-old leaves were not different from those in 1-week-old leaves. Both 132PUI and 90PUI plants had a moderate expression level in 1-week-old leaves. However, the expression was reduced to $75 \%$ of that for $132 \mathrm{PUI}$ plants in 2 -week-old leaves, but remained steady for 90PUI plants. These results suggest that atTOC159, atTOC120 and atTOC90 are expressed at a constant level through the developmental stages of vegetative growth. In contrast, atTOC132 expression was related to plant age, with highest promoter activity in the young leaves and a settled yield in the mature leaves. From above, it is obviously that atTOC159 expression is predominantly and constantly expressed whereas atTOC132 is modulated in an age-dependent manner in leaves.

Next, the expression differences of atTOC159 homologous genes in 3-week-old roots were determined. The expression levels of atTOC159 and atTOC132 were similar and both were approximately three times higher than those of atTOC120 and atTOC90 (Figure 2). This reveals that atTOC159 and atTOC132 play a more significant role than others in roots. In fact, atTOC120 and atTOC90 seemed expressing at a basal level when compared to control construct p1391Z. This implies that atTOC120 and atTOC90 might not important for the root function. However, atTOC90 expression in both 1-

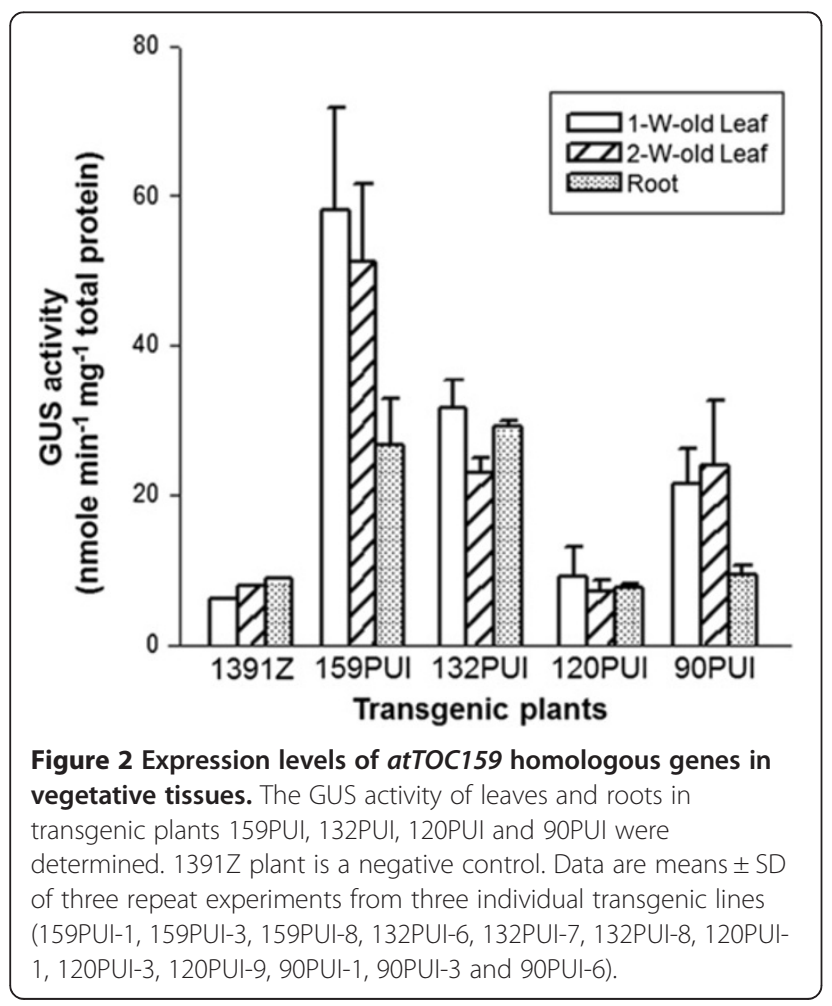

week-old and 2-week-old leaves was about 2.5 times higher than in roots, suggesting that atTOC 90 is preferentially expressed in leaves. Similar to the expression pattern of atTOC90, atTOC159 expression in leaves was approximately 2 times higher than in roots, indicating that atTOC159 is also preferentially expressed in leaves. Altogether, among the members of atTOC159 gene family in Arabidopsis, the expression level of atTOC159 is the highest in all vegetative tissues and atTOC159 preferentially expressed in leaves. The atTOC132 is moderately expressed in all tissues and is regulated in an age-specific manner in leaves. The atTOC120 is poorly expressed in all tissues. Finally, atTOC 90 is modestly and preferentially expressed in leaves, but barely expressed in roots.

\section{Differential expression of atTOC159 homologous genes in reproductive tissues}

In order to understand if the expression of atTOC159 homologous genes was modulated by developmental signals in reproductive tissues, GUS activity of flower buds and different stages of siliques collected from various transgenic plants was determined. In flower buds and $0.5-\mathrm{cm}$ siliques, the GUS activity of 159PUI, 132PUI, 120PUI and 90PUI was alike and about 2 to 3 times higher than that of control plant $1391 \mathrm{Z}$ (Figure 3). In $1.0-\mathrm{cm}$ siliques, the GUS activity of 132PUI, 120PUI and 90PUI remained about 2 times higher than that of 1391Z, but the

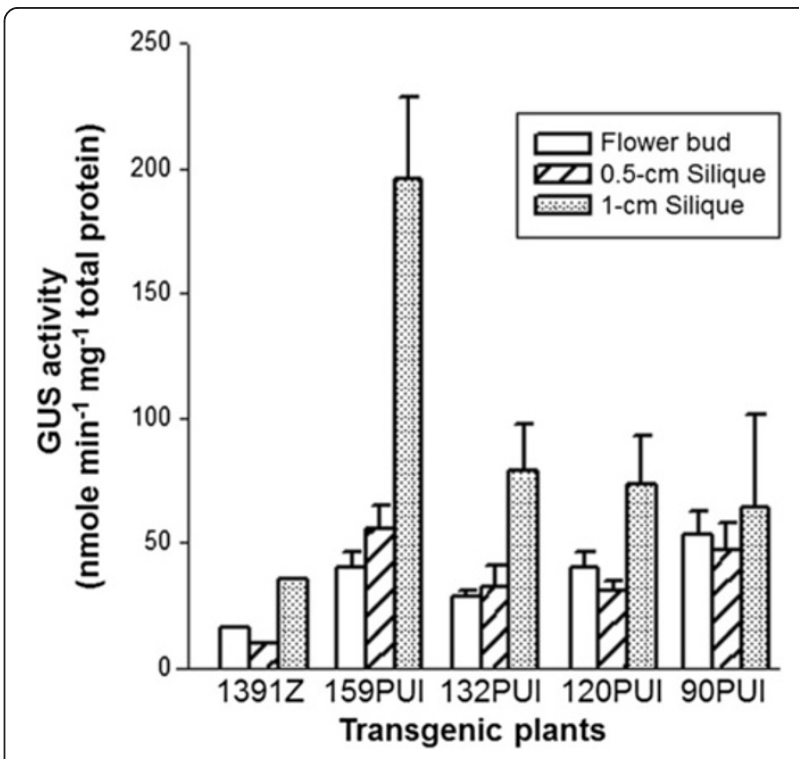

Figure 3 Expression of atTOC159 homologous genes in reproductive tissues. The GUS activity of flower bud, $0.5-\mathrm{cm}$ silique and $1-\mathrm{cm}$ silique in transgenic plants 159PUI, 132PUI, 120PUI and 90PUI were determined. 13912 plant is a negative control. Data are means \pm SD of three repeat experiments from three individual transgenic lines (159PUI-1, 159PUI-3, 159PUI-8, 132PUI-6, 132PUI-7, 132PUI-8, 120PUI-1, 120PUI-3, 120PUI-9, 90PUI-1, 90PUI-3 and 90PUI-6). 
GUS activity of 159PUI was 4.6 times higher than that of $1391 \mathrm{Z}$ (Figure 3). These data indicate that atTOC159, atTOC132, atTOC120 and atTOC90 all participate in the regulation of the flower and fruit development. In addition, atTOC159 appears to have a greater role during late fruit development.

\section{Up-regulation of atTOC 120 and atTOC90 by their endogenous leader intron}

Leader intron in $5^{\prime}$ UTR is to moderate the level and pattern of gene expression in Arabidopsis (Norris et al., 1993; Jeong et al., 2006; Chen and Sun, 2010). The mechanism of intron-mediated enhancement (IME) is largely unknown, but IME might increase transcription efficiency or mRNA stability (Rose et al., 2008). As atTOC132, atTOC120 and atTOC90 have similar gene structures and include intron in $5^{\prime}$ UTR, we want to examine whether the leader intron sequences play a role in regulating the atTOC132, atTOC120 and atTOC90 expression in stable transgenic plants. With similar strategies, the pCAMBIA1391Z-based transgenes containing upstream sequence and 5' UTR prior to endogenous leader intron sequence were transformed into wild type Arabidopsis to create 132P, 120P and 90P transgenic plants (Figure 1). The p132P plasmid contained 383-bp promoter and 74-bp 5' UTR sequences of atTOC132. The p120P plasmid contained 673-bp promoter and 23-bp 5' UTR sequences of atTOC120. The p90P plasmid included 575-bp promoter and 56-bp 5' UTR sequences of atTOC90. The precise position of $5^{\prime}$ UTR and intron of atTOC159 is undetermined, so its intron effect is not able to verify in this study. Twenty three, fifty and eleven independent transgenic lines containing construct p132P, p120P and p90P, respectively, were identified. They were named 132P-1 23, 120P-1 50 and 90-1 11. Three homozygous 132P (132P-1, 132P-13, 132P-19), three homozygous $120 \mathrm{P}$ (120P-3, 120P-12, 120P28 ) and three homozygous $90 \mathrm{P}$ (90P-1, 90P-3, 90P-9) $\mathrm{T}_{3}$ transformants were used for further GUS analyses.

The GUS activity of three transgenic lines contained the same construct from 5-day-old seedlings, 2-week-old leaves, and mature flowers was examined histochemically. Plant 132PUI-7, 132P-13, 120PUI-3, 120P-28, 90PUI-3 and 90P-9 were representatives in Figure 4. The 132PUI and 132P plants had similar GUS activity in all tissues examined. However, compared to $120 \mathrm{P}$ plant, 120PUI plant had obviously higher GUS activity in root tips, rosette leaves, and mature flowers. In comparison with 90P plant, 90PUI had higher GUS activity in cotyledons, rosette leaves and flowers, significantly notable in anthers. These data reveal that the endogenous intron sequence indeed up-regulates atTOC132 and atTOC90 expression in a tissue-specific manner, but it has no effect in moderating atTOC132 expression.

\section{Discussion}

Previous genetic and biochemical studies suggested that atToc159 and atToc90 were important for the accumulation of photosynthetic proteins during chloroplast development. The knockout Arabidopsis mutants of atTOC159 and atTOC90 were named ppi2 (plastid protein import 2, or attoc159) and ppi4 (or attoc90), respectively. The ppi2 mutant resulted in an albino seedling that was not able to grow beyond the cotyledon stage on soil (Bauer et al., 2000). The ppi2 plastids failed to accumulate massive amount of photosynthetic proteins, and therefore lacked thylakoids and starch granules. Nevertheless, the residual amounts of non-photosynthetic proteins in ppi2 plastid were not less than those of wild type plastid, underlining the importance of atToc159 for chloroplast development (Bauer et al., 2000). The ppi4 mutant had no obvious phenotype (Hiltbrunner et al. 2004). However, ppi2/ppi4 double mutant appeared a paler phenotype than ppi2 single mutant, revealing a functional overlap between atToc159 and atToc90 (Hiltbrunner et al. 2004). Nonetheless, overexpression of atTOC90 partially complemented the ppi2 defect, demonstrating atToc90 could only contribute to the import route for some atToc159 client proteins (Infanger et al., 2011). The severity of phenotypic defect could be linked to our transgene results. The steady expression level of atTOC159 in light-grown young leaves is much higher than that of atTOC90 (Figure 2), suggesting that atToc159 plays a more significant roles as the receptor of photosynthetic proteins in leaves and cotyledons.

By contrast, atToc132 and atToc120 seemed to be more specific for recognizing and importing non-photosynthetic proteins (Ivanova et al., 2004; Kubis et al., 2004). AtToc132 (and atToc120) was selectively binding to the transit peptide of preE1 $\alpha$, prepyruvate dehydrogenase E1a subunit representing a non-photosynthetic protein in plastid, rather than binding to the transit peptide of preSSU, presmall subunit of Rubisco representing the photosynthetic protein in chloroplast (Ivanova et al., 2004). The plastids in root of homozygous attoc132/attoc120 double mutant had irregular shape and contained large cytoplasmic inclusions (Kubis et al. 2004). Stanga et al. (2009) recently reported that overexpression of atTOC132 rescued the defect of gravitropism sensing and signaling in arg1 (altered response to gravity 1) and mar2 (modifier of ARG1, identified as atToc132 now) double mutant, revealing atToc132 to involve in gravity signal transduction within the plastid. These studies clearly suggest that atTOC132 and atTOC120 indeed play important roles in regulating root development. From above, atToc132 and atToc120 appear to preferentially affect the import of non-photosynthetic preproteins. However, expression of atTOC120 failed to complement attoc132/attoc120 double mutant, suggesting atToc120 was not sufficient to recognize most of non- 


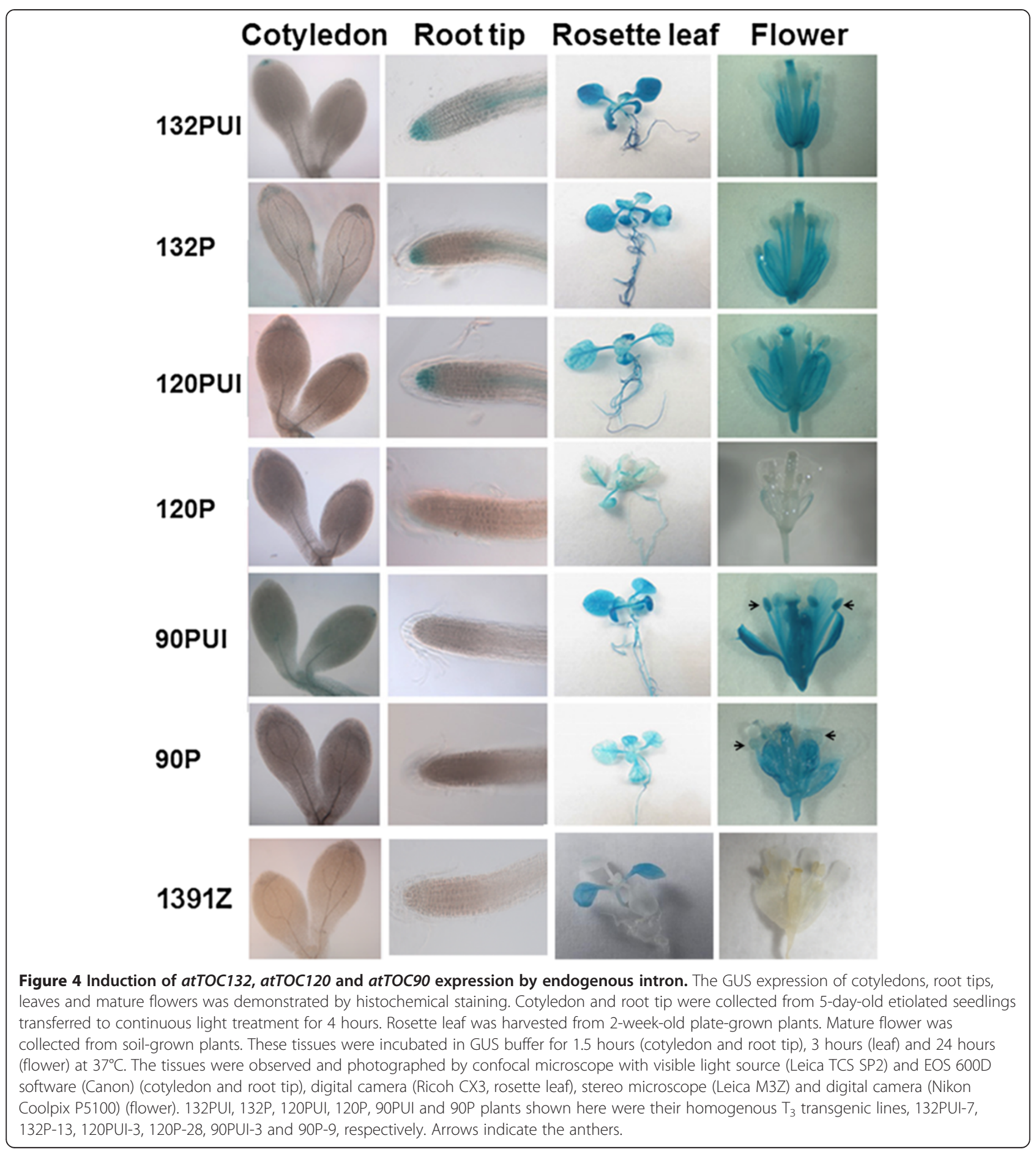

photosynthetic proteins. This is probably due to the low expression yield of atTOC120 in Arabidopsis. Our data in this study indicated that the expression level of atTOC132 in leaves and roots was higher than that of atTOC120 (Figure 2), pointing out that atToc132 devotes more in the machinery of non-photosynthetic protein import.

Recent large-scale proteomic studies have raised the question whether it is suitable to categorize atToc159 and atToc132 as major receptors of photosynthetic and non-photosynthetic preproteins, respectively. Based on the comparative analysis of plastid proteome from two attoc159 knockout mutants to wild type plant, many photosynthetic proteins accumulated but several metabolic proteins decreased in attoc159 plastids (Bischof et al., 2011). This suggested that atToc159 was responsible for recognition of both photosynthetic and non- 
photosynthetic proproteins. Therefore, the authors defined the plastid preproteins as atToc159-dependent and atToc159-independent precursor proteins. Furthermore, the comparative analysis of chloroplast proteome between attoc132 mutant and wild type plant showed that the abundances of four photosynthetic-related and five non-photosynthetic proteins increased 1.5 to 2.5 folds, but five non-photosynthetic proteins decreased approximately 2 folds (Kubis et al., 2004). The accumulation of most chloroplastic proteins remained the similar yield. Theses research work might underestimate the function of atToc90 and atToc120. Except for the pale phenotype of ppi2 (attoc159 mutant), attoc132, attoc120 and ppi4 (attoc90) single mutant did not have any visible phenotype. However, ppi2/ppi4 double mutant appeared a paler phenotype than ppi2 single mutant (Hiltbrunner et al. 2004), and attoc132/attoc120 double mutant showed pale green (Kubis et al., 2004) or were even embryo lethal (Ivanova et al., 2004), revealing a functional overlap between atToc159 and atToc90, or between atToc132 and atToc120. It might be more informative to characterize substrate specificity of these atToc159 isoforms by the plastid proteome from double mutant to single mutant or wild type plants.

Even though atTOC159 gene members tend to differentially express in various vegetative tissues, they all participate in flower and fruit development (Figure 3). Our data suggested that these genes had high expression in flower and early fruit development, and significantly higher expression level in later fruit development (Figure 3). These results were supported by previous genetic studies. For example, the single mutant of each gene is able to produce seeds with normal viability. However, homozygous attoc159/attoc132 and attoc132/ attoc120 double mutants cause embryo lethality (Ivanova et al., 2004; and Kubis et al., 2004). Therefore, we conclude that all atToc159 isoforms are not only contributed to the import of photosynthetic/non-photosynthetic related proteins during vegetative growth, but also modulate reproductive growth.

The enhancing effects of gene expression by introns were first reported by (Mascarenhas et al. 1990) and the function was defined as IME. Even though the mechanism of IME remains largely unknown, the effect of IME has been broadly observed in eukaryotes, including animals and plants (Jonsson et al., 1990; Palmiter et al., 1991; Rethmeier et al., 1998; Morello et al., 2002; Jeong et al., 2006; Chen and Sun, 2010). Our stable transformation assay suggested the intron sequence of atTOC132 did not alter its expression yield in cotyledons, root tips, rosette leaves, and flowers (132PUI and 132P in Figure 4). Nevertheless, the intron sequence of atTOC120 and atTOC90 indeed increased the expression yield obviously. The endogenous intron sequence up-regulated atTOC120 expression level specifically in root tips and flowers, but not in cotyledons (120PUI and 120P in Figure 4). In contrast with atTOC120, the intron sequence induced atTOC90 expression level specifically in cotyledons, leaves and anthers, but not in root tips and rest of flower tissues (90PUI and 90P in Figure 4). These findings imply that the intron effect of atTOC120 is more effective in roots and whole flowers, and atTOC90 is in cotyledons, leaves and anthers. We thus hypothesized that these introns might contain tissue-specific enhancers. Additional experiments are clearly required to prove this hypothesis.

The level of GUS activity in 1-or 2-week-old leaves and 3-week-old roots of 120PUI plant was similar to $1391 \mathrm{Z}$ control plant (Figure 2). This seemed to imply that 120PUI did not express GUS gene. However, 120PUI plant showed a moderate GUS expression level in the 5day-old root tips and 2-week-old rosette leaves (Figure 4). These conflict results might be due to the binary vector pCAMBIA1391Z used in this transgenic study. Even though pCAMBIA1391Z contains a promoter-less GUS gene, a nearby cauliflower mosaic virus (CaMV) 35S promoter which drives the expression of hygomycin phosphotransferase II (HptII) gene, could also drive the expression of GUS gene. In consequence, the transgenic plants containing pCAMBIA1391Z show a low to moderate level of GUS expression in various tissues (http:// www.cambia.org). Based on this rationale, 120PUI plant indeed expresses the GUS gene in leaves and root tips, and the expression level is similar to $1391 \mathrm{Z}$ control plant. Besides, the GUS activity of leaves in 120P plant was lower than $1391 \mathrm{Z}$ plant (Figure 4). It is possible that an actively expressed gene can suppress the expression of a close-by gene, especially a weakly expressed gene. For example, unlike most of polyubiquitin $(U B Q)$ genes in Arabidopsis which had an abundantly expressed yield, the expression level of $U B Q 4$ was barely detected in all tissues (Sun and Callis, 1997). Carter et al. (1998) indicated thereafter that $U B Q 4$ expression was suppressed by a strongly expressed nearby gene, germin-like protein $3 \mathrm{~b}(G L P 3 b)$, which was approximately $500 \mathrm{bp}$ upstream of $U B Q 4$ transcription start site. Altogether, we conclude that pCAMBIA1391Z vector may not be appropriate to determine the absolute expression level of weakly expressed genes, but still feasible to compare the relative expression level of these genes in transgenic plants.

\section{Conclusions}

Due to their recognition of different substrate proteins during protein import into plastids, the closely related atTOC159 homologous genes are independently or coordinatedly regulated in response to developmental signals to ensure the proper import of plastid proteins. Based on the results from stable transgenic plants expressing GUS reporter, we conclude that the upstream 
regulatory sequences of atTOC159 homologous genes govern the differential expression of these genes among vegetative and reproductive tissues. Furthermore, the endogenous leader intron sequences of atTOC120 and atTOC90 up-regulate gene expression in a tissuespecific manner.

\section{Abbreviations}

GUS: $\beta$-glucuronidase; PCR: Polymerase chain reaction; Tic/Toc: Translocon at the inner/outer envelope membrane of the chloroplast; 5' UTR: 5' untranslated region.

\section{Competing interests}

The authors declare that they have no competing interests.

\section{Authors' contributions}

YSL carried out the molecular genetic and biochemical studies. CWS participated in drafting and revising the manuscript. Both authors read and approved the final manuscript.

\section{Acknowledgements}

This work was supported by grants to CWS from the National Science Council of Taiwan (NSC 98-2311-B-003-002 and NSC 99-2311-B-002-MY3).

Received: 16 September 2013 Accepted: 16 September 2013 Published: 25 September 2013

\section{References}

Bauer J, Chen K, Hiltbunner A, Wehrli E, Eugster M, Schnell D, Kessler F (2000) The major protein import receptor of plastids is essential for chloroplast biogenesis. Nature 403:203-207

Bischof S, Baerenfaller K, Wildhaber T, Troesch R, Vidi PA, Roschitzki B, HirschHoffmann M, Hennig L, Kessler F, Gruissem W, Baginsky S (2011) Plastid proteome assembly without Toc159: photosynthetic protein import and accumulation of $\mathrm{N}$-acetylated plastid precursor proteins. Plant Cell 23:3911-3928

Carter C, Graham RA, Thornburg RW (1998) Arabidopsis thaliana contains a large family of germin-like proteins: characterization of cDNA and genomic sequences encoding 12 unkque family members. Plant Mol Biol 38:929-943

Chen YJ, Sun CW (2010) Transgenic study of chloroplast translocon gene regulation in Arabidopsis thaliana. Bot Stud 51:147-153

Clough SJ, Bent AF (1998) Floral dip: a simplified method for Agrobacteriummediated transformation of Arabidopsis thaliana. Plant J 16:735-743

Fan SC, Lin CS, Hsu PK, Lin SH, Tsay YF (2009) The Arabidopsis nitrate transporter NRT1.7, expressed in phloem, is responsible for source-to-sink remobilization of nitrate. Plant Cell 21:2750-2761

Hiltbrunner A, Grunig K, Alvaez-Huerta M, Infanger S, Bauer J, Kessler F (2004) AtToc90, a new GTP-binding component of the Arabidopsis chloroplast protein import machinery. Plant Mol Biol 54:427-440

Inaba T, Schnell DJ (2008) Protein trafficking to plastids: one theme, many variations. Biochem J 413:15-28

Infanger S, Bischof S, Hiltbrunner A, Agne B, Baginsky S, Kessler F (2011) The chloroplast import receptor Toc90 partially restores the accumulation of Toc159 client proteins in the Arabidopsis thaliana pp i2 mutant. Mol Plant 4:252-263

Ivanova Y, Smith MD, Chen K, Schnell DJ (2004) Members of the Toc159 import receptor family represent distinct pathways for protein targeting to plastids. Mol Biol Cell 15:3379-3392

Jarvis P, Chen LJ, Li HM, Peto CA, Fankhauser C, Chory J (1998) An Arabidopsis mutant defective in the plastid general protein import apparatus. Science 282:100-103

Jarvis P (2008) Targeting of nucleus-encoded proteins to chloroplasts in plants. New Phytol 179:257-285

Jefferson RA (1987) Assaying chimeric genes in plants: the GUS gene fusion system. Plant Mol Biol Rep 5:387-405

Jeong YM, Mun JH, Lee I, Woo JC, Hong CB, Kim SG (2006) Distinct roles of the first introns on the expression of Arabidopsis profile in gene family members. Plant Physiol 140:196-209

Jonsson JJ, Foresman MD, Wilson N, Mclvor RS (1990) Intron requirement for expression of the human purine nucleoside phosphorylase gene. Nucleic Acids Res 20:3191-3198
Kubis S, Baldwin A, Patel R, Razzaq A, Dupree P, Lilley K, Kurth J, Leister D, Jarvis P (2003) The Arabidopsis pp i1 mutant is specifically defective in the expression, chloroplast import, and accumulation of photosynthetic proteins. Plant Cell 15:1859-1871

Kubis S, Patel R, Combe J, Bédard J, Kovacheva S, Lilley K, Biehl A, Leister D, Ríos G, Koncz C, Jarvis P (2004) Functional specialization amongst the Arabidopsis Toc159 family of chloroplast protein import receptors. Plant Cell 16:2059-2077

Martin W, Rujan T, Richly E, Hansen A, Cornelsen S, Lins T, Leister D, Stoebe B, Hasegawa M, Penny D (2002) Evolutionary analysis of Arabidopsis, cyanobacterial, and chloroplast genomes reveals plastid phylogeny and thousands of cyanobacterial genes in the nucleus. Proc Natl Acad Sci USA 99:12246-12250

Mascarenhas D, Mettler IJ, Pierce DA, Lowe HW (1990) Intron-mediated enhancement of heterologous gene expression in maize. Plant Mol Biol 15:913-920

Morello L, Bardini M, Sala F, Breviario D (2002) A long leader intron of the Ostub16 rice $\beta$-tubulin gene is required for high-level gene expression and can autonomously promote transcription both in vivo and in vitro. Plant J 29:33-44

Murashige T, Skoog F (1962) A revised medium for rapid growth and bioassays with tobacco tissue culture. Physiol Plant 15:473-497

Norris SR, Meyer SE, Callis J (1993) The intron of Arabidopsis thaliana polyubiquitin genes is conserved in location and is a quantitative determinant of chimeric gene expression. Plant Mol Biol 21:895-906

Palmiter RD, Sandgren EP, Avarbock MR, Allen DD, Brinster RL (1991) Heterologous introns can enhance expression of transgenes in mice. Proc Natl Acad Sci USA 88:478-482

Rethmeier N, Kramer E, Va M, Montagu N, Cornelissen M (1998) Identification of cat sequences required for intron-dependent gene expression in maize cells. Plant J 13:831-835

Rose AB, Elfersi T, Parra G, Korf I (2008) Promoter-proximal introns in Arabidopsis thaliana are enriched in dispersed signals that elevate gene expression. Plant Cell 19:1898-1911

Stanga JP, Boonsirichai K, Sedbrook JC, Otegui MS, Masson PH (2009) A fole for the TOC complex in Arabidopsis root gravitropism. Plant Physiol 149:1896-1905

Sun CW, Callis J (1997) Independent modulation of Arabidopsis thaliana polyubiquitin mRNAs in different organs and in response to environmental changes. Plant J 11:1017-1027

Zimmermann P, Hirsch-Hoffmann M, Hennig L, Gruissem W (2004) GENEVESTIGATOR: Arabidopsis microarray database and analysis toolbox. Plant Physiol 136:2621-2632

\section{doi:10.1186/1999-3110-54-40}

Cite this article as: Liu and Sun: Characterization of differential expression and leader intron function of Arabidopsis atTOC159 homologous genes by transgenic plants. Botanical Studies 2013 54:40.

\section{Submit your manuscript to a SpringerOpen ${ }^{\circ}$ journal and benefit from:}

- Convenient online submission

- Rigorous peer review

- Immediate publication on acceptance

- Open access: articles freely available online

- High visibility within the field

- Retaining the copyright to your article

Submit your next manuscript at $\boldsymbol{\wedge}$ springeropen.com 